\title{
Mediating role of coping styles in personal, environmental and event related factors and posttraumatic growth relationships in women with breast cancer
}

\author{
Meme kanseri olan kadınlarda bireysel, çevresel ve olaya dair faktörler ile \\ travma sonrası gelişim ilişkileri arasında başa çıkma stillerinin aracılık rolü
} Zumrut Bellur ${ }^{1}$, Arzu Aydın², Emre Han Alpay ${ }^{1}$

${ }^{1}$ Res. Ass, ${ }^{2}$ Assoc.Prof., Mersin University, Faculty of Arts and Sciences, Department of Psychology, Mersin, Turkey

\section{SUMMARY}

Object: The aim of this study was to examine the effects of environmental, personal and event related factors on posttraumatic growth in breast cancer patients. Methods: The study was conducted with 134 women who are undergoing chemotherapy treatment or coming to the hospital for their routine controls. Revised Dyadic Adjustment Scale, The Impact of Event Scale, Posttraumatic Growth Inventory, Ways of Coping Inventory, Multidimensional Scale of Perceived Social Support, The General Self-Efficacy Scale-Turkish Form and Demographic Information Form was used. Results: Acoording to t-test analyses as the time passage from the diagnosis increases the perceived social support from the family members is increasing. Also while the group that had previous trauma experiences uses more helplessness coping styles, the group that had no previous trauma experience uses more problem focused coping style and showed greater posttraumatic growth. Results of the mediation analyses showed that problem focused coping has a mediator role in dyadic adjustment- posttraumatic growth; perceived social support from the family- posttraumatic growth; and self-efficacy- posttraumatic growth relationships. Discussion: The results of the current study are important in terms of developing new intervention programs that will help breast cancer patients to develop posttraumatic growth and also to better cope with cancer. This study is also important because the effect of marital adjustment and marital satisfaction on posttraumatic growth in breast cancer patients is an issue which is not well studied with Turkish sample.

Key Words: Posttraumatic growth, marital adjustment, coping styles, breast cancer

\section{ÖZET}

Amaç: Bu araştırmanın amacı meme kanseri hastalarında çevresel, bireysel ve olaya dair faktörlerin travma sonrası gelişim ile olan ilişkisini incelemektir. Yöntem: Çalışma kemoterapi tedavisi ya da rutin kontrolleri için hastaneye gelen 134 kadın ile yürütülmüştür. Çalışma kapsamında Yenilenmiş Çift Uyum Ölçeği, Olay Etkisi Ölçeği Gözden Geçirilmiş Formu, Travma Sonrası Gelişim Ölçeği, Başa Çıkma Yolları Envanteri, Çok Boyutlu Algılanan Sosyal Destek Ölçeği, Genel Özyeterlilik Ölçeği ve Demografik Bilgi Formu kullanılmıştır. Bulgular: T-testi analizi sonuçlarına göre tanı almanın üzerinden geçen zaman arttıkça aileden algılanan sosyal desteğin arttığı görülmüştür. Tanı almadan önce travma deneyimi olan katılımcılar daha çok çaresiz başa çıkma sitili kullanırken, tanı öncesinde travma yaşamamış olanlar daha çok problem odaklı başa çıkma stili kullanıp daha yüksek travma sonrası gelişim rapor etmişlerdir. Aracılık testi sonuçları problem odaklı başa çıkma stilinin; çift uyumu-travma sonrası gelişim; aileden algılanan sosyal destek-travma sonrası gelişim; genel özyeterlilik-travma sonrası gelişim ilişkilerinde tam aracılık rolü olduğunu göstermiştir. Sonuç: Çalışmanın bulguları kanser hastalarına yönelik daha iyi baş etme yolları ve travma sonrası gelişim geliştirebilmelerine yardımcı olabilecek müdahaleler geliştirilebilmesi açısından önemlidir. Ayrıca çalışma meme kanseri hastalarında travma sonrası gelişim ile evlilik uyumu ve evlilik doyumu arasındaki ilişkinin Türkiye'de çok az çalışılan bir konu olmasından dolayı önemlidir.

Anahtar Sözcükler: Travma sonrası gelişim, evlilik uyumu, başa çıkma stilleri, meme kanseri 


\section{INTRODUCTION}

Human beings have been exposed to accidents, wars, terrorist attacks, losses and natural disasters ever since the beginning of the mankind's existence. Such traumatic experiences may cause some psychological disorders in people who experience them, like posttraumatic stress disorder. In addition, chronic illnesses can also be defined as traumatic for the patients and for their families in terms of the effects they have on these people.

Fortunately, traumatic events do not always end up with a disorder or a pathology. According to the literature, apart from their negative effects, traumatic events lead to some positive results for some people $(1,2)$. In their study, which examines the changes resulting from traumas, Tedeschi, Park and Calhoun (3) reported that it is important to take into account both the negative and the positive psychological results of traumas to arrive at more comprehensive conclusions. Posttraumatic growth (PTG), which is well defined by Tedeschi and Calhoun (4), refers to the positive changes that are experienced as a result of trying to cope with threatening life events. According to the literature, people who experience traumatic events not only recover but they also go far beyond their functioning level prior to the traumatic event. NolenHoeksema and Davis (5) stated that changes occurring as a result of trying to cope with the distressing situation bring the person to a higher functioning level prior to the traumatic event.

There are a plenty of models developed to define the term PTG and other related variables. Some of these models are: PTG as one construal of meaning (6), PTG within a meaning-making coping process (7), PTG as an interpretative process (8), PTG as one form of self-enhancing appraisal or positive illusion (9), model of life crises and personal growth (10) and conceptual model of PTG (4).

According to the conceptual model of posttraumatic growth, which is developed by Tedeschi and Calhoun (4), characteristics of the event and the person -stress management, ruminations, disclosure, and socio-cultural factors (schema models for post traumatic growth, social themes)- are related factors with posttraumatic growth.

Schaefer and Moos (11) proposed that personal and environmental systems affect life crises and in turn, they shape the results of these crises. According to this model, personal system consists of demographic characteristics, self-efficacy, hardiness, motivation, health status and prior trauma experiences. Relationships with family, friends and coworkers and the perceived social support from these sources all together generate the environmental system. Moreover, financial status, home environment and social life can also be included within the environmental factors. Event related factors are the duration, severity and timing of the event and also the scope of the event (whether it affects only the person or it affects a group of people). In addition to these factors, the strategies used to cope with/manage these traumatic events refer to the cognitive processes (11).

Zemore and Shepel (12) reported that social support not only influences the coping strategies but it also helps the person to successfully adjust to life crisis which in turn results in PTG. Another result of this study was related to the severity of the event, that is, as the severity increases, the social support also increases and it leads to higher PTG (12). Moos and Schaefer (13) reported that individuals who get more support from their family and friends are more prone to use approach coping. Moreover, it was stated that using approach coping more was related with increased adjustment to life crises and decreased psychological symptoms (13). Furthermore when compared with avoidant coping; approach coping is highly related with PTG (10). Likewise in another study it was found that postoperative breast cancer (BC) patients who were optimistic were more likely to use problem-focused coping strategies which leads to the development of posttraumatic growth (14). Some of the studies regarding the relationship between chronic illnesses and PTG examined the relationship between HIV infection and PTG (15), rheumatoid arthritis and PTG (16), and autism and PTG (17). Schwartzberg (15) stated that most of the gay men who are HIV infected gained insight about their positive characteristics. According to findings of this study, being diagnosed as HIV-positive for some men, was a transforming experience, because 
this experience helped them to see their strong aspects, skills and also helped them to explore their internal resources (15). Elçi (17) in his study with the parents of autistic children found that social support and problem solving/optmistic coping were significant predictors of PTG among mothers. On the other hand, social support, problem solving/optimistic coping, religiosity, age, years of marriage were the significant predictors of PTG among fathers (17). Finally, Dirik (16) in her research about rheumatoid arthritis, found that, gender (being female), perceived severity of the illness, perceived social support and problem solving coping were significant predictors of PTG where as religiousness was not found to be related to PTG (16).

Cancer confronts people with the probability of their own death. When it comes to death, many of the cancer patients begin to think deeply about the meaning of life, purpose of life, beliefs in God or not believing in God and spirituality. For some patients this kind of existential thoughts leads to an increase in the value of life and to a stronger or clearer feeling of spirituality (2). In another study conducted with cancer patients, it was shown that some characteristics of cancer experience lead to posttraumatic growth in patients (18). Also in another study it was found that post traumatic growth is highly common in cancer patients that is most of the cancer patients develop a more positive manner to not only themselves but also to their families and to other people (11). Finally, when the studies that specifically assessed the relationship between breast cancer and posttraumatic growth are examined, some of the variables found to be related to PTG are as follow; social support and ways of coping (19); problem focused coping and dispositional optimism (14); perceived social support from significant others and dispositional optimism (20).

Individuals diagnosed with cancer are faced with different types of stressful experiences like; being diagnosed with a serious disease, being exposed to medical interventions, possibility of relapse, adverse effects of the treatment, impairments in physical and social functioning $(21,22)$.
The most prevalent cancer type among Turkish women is breast cancer with a percentage of 43 (23). The purpose of the current study was to examine the relationship between environmental, personal and event related factors and posttraumatic growth in breast cancer patients. For this aim, hypotheses of the current study are as follows;

- Posttraumatic growth will increase as perceived social support increases.

- PTG will increase as self-efficacy increases.

- PTG will increase as avoidance increases, whereas, hypervigilance will decrease as PTG increases.

- As optimistic/problem focused coping and fatalistic coping increases, PTG will increase. On the other hand, as helplessness coping increases PTG will decrease.

- Optimistic/problem focused coping style will mediate the PTG-environmental factors, PTGindividual factors and PTG-event related factors relationships.

- Fatalistic coping style will mediate the PTG-environmental factors, PTG-individual factors and PTG-event related factors relationships.

- Helplessness coping style will not mediate the PTG-environmental factors, PTG-individual factors and PTG-event related factors relationships.

- Age, duration of marriage, time since the diagnosis, education and prior trauma experiences will be related with PTG.

\section{METHOD}

\section{Participants}

One hundred and thirty four women breast cancer patients (mean age $=45.02, \mathrm{SD}=8.18$, range $=23$ 67) undergoing postoperative chemotherapy treatment, radiotherapy treatment or coming to the hospital for their routine controls after recovery par- 
ticipated in the study. Participants were recruited from different cities in Turkey, which are Gaziantep, Bursa, Mersin, İzmir and Adana. The participants had a history of breast cancer for a minimum of two months and a maximum of 180 months $(\mathrm{M}=27.92, \mathrm{SD}=37.13)$. Thirty-two of the participants (\% 23.9) had trauma experience (serious accident, natural disaster, physical assault, torture, serious illness, death of a loved one) prior to their diagnosis of breast cancer whereas one hundred and two of the participants (\% 76.1) had no trauma experience prior to their diagnosis of breast cancer. While one hundred of the participants ( $\%$ 74.6) were unemployed, twenty seven of the participants (\% 20.2) were currently employed in different jobs (engineer, teacher, officer etc.) and finally seven of the participants (\% 5.2) were retired (see table 1). Inclusion criteria for the sample were being at least 18 year old and being married, having a history of breast cancer for a minimum of two months and maximum of 180 months.

\section{Measures}

Multidimensional Scale of Perceived Social Support (MSPSS): The MSPSS, which was originally developed by Zimet, Dahlem, Zimet and Farley (24) was used in the present study. It was translated into Turkish by Eker and Arkar (25) and revised by Eker, Arkar, and Yaldız (26). The scale consists of 12 likert items questioning the source and the level of social support provided by a significant other, family members and friends (26). The scale is a seven-point Likert-type questionnaire and higher scores represent higher levels of perceived social support. The factor analysis of the MSPSS for the present study yielded three factors explaining 62.49 percent of the variance. In the present study, the internal consistency measured by Cronbach alpha of the whole scale was 0.79 , significant other was 0.83 , family was 0.55 and friends subscale was 0.85 illustrating good reliability.

Posttraumatic Growth Inventory (PTGI): The PTGI was developed by Tedeschi and Calhoun (4) to measure the positive changes resulted after traumatic experiences. The scale was translated into Turkish by Kılıç (27). The revised and adapted form by Dirik and Karancı (28) was used in the current study. The PTGI consisted of 21 six-point likert items and divided into five subscales which are new possibilities, relating to others, personal strength, spiritual change and appreciation of life. Although this scale consists of five subscales, Bellizzi and colleagues (29) stated that factor analysis showed that the inventory appeared to reflect one global construct rather than several distinct areas of growth. Similarly Park and Lechner (30) stated that total score was used due to such inconsistencies regarding the factor structure of the scale. Likewise, in the current study total score was used as an indicator of growth: posttraumatic growth rate increases as the score increase. In the present study, the internal consistency reliability of the PTGI calculated by Cronbach's alpha was 0.86 .

Ways of Coping Inventory (WCI): Ways of Coping Inventory (WCI) was developed by Folkman and Lazarus (31) and revised by Folkman and Lazarus (32) to measure the coping strategies. Uçman (33)

Table 1. Demographic characteristics of the participants

\begin{tabular}{lcc}
\hline & Frequency & Percentage \\
\hline Work Status & & 20.1 \\
Working & 27 & 74.6 \\
Not Working & 100 & 5.2 \\
Retired & 7 & \\
Education & 2 & 1.5 \\
Master Degree & 22 & 16.4 \\
University Graduate & 33 & 24.6 \\
High School Graduate & 69 & 51.5 \\
Primary School Graduate & 8 & 6.0 \\
No Education & & \\
Prior Trauma Experience & 32 & 23.9 \\
Yes & 102 & 76.1 \\
No & & \\
\hline
\end{tabular}


stated that the scale was translated into Turkish in 1998 by Siva. Karanci et al. (34) used the shortened form (42 three-point likert items and four factors) in their study, which measures the relationship between ways of coping and psychological distress of earthquake survivors in Turkey. The form that was used by Karanci et al. (34) was used in the current study. The factor analysis made by using principal component analysis with varimax rotation of the WCI for the present study, yielded three factors explaining 35.86 per cent of the variance. According to the factor analysis, some of the items of optimistic coping loaded under the factor, which is named as problem focused coping. It can be said that the ones who use problem focused coping style are optimistic and their problem solving strategies are positive. According to Bell and D'Zurilla (35) "a positive problem orientation consists of the general disposition to a) appraise a problem as a challenge, b) believe that problems are solvable, c) believe in ones ability to solve problems effectively and d) recognize and accept the fact that effective problem solving takes time and effort". From this point of view, it was thought that optimism is the first requirement for the problem focused coping style. Thus, this factor, which mostly consists of the items related to optimistic coping and problemfocused coping is named as Problem focused/optimistic coping style. The Chronbach's alpha of the total scale was 0.80 while the Cronbach's alpha for Optimistic/ Problem focused coping was 0.80, for fatalistic coping was 0.78 and for helplessness coping was 0.69 .

The General Self-Efficacy Scale-Turkish Form: The General Self-Efficacy Scale was developed by Sherer et al. (36) and consisted of 23 items. Turkish version of the scale readapted by Yildırım and Illhan (37) was used in the present study. The questionnaire consisted of 17 five-point likert items. The original scale divided into three subscales but the total score was used in the present study as it was suggested by Yildırım and İlhan (37) (as the score increases self-efficacy increases). In the present study, the internal consistency of the General Self-Efficacy Scale-Turkish Form calculated by Cronbach's alpha was 0.86 .

Revised Dyadic Adjustment Scale (R-DAS): Dyadic Adjustment Scale (DAS) was developed by Spanier
(38) to measure the quality of the marriage. The original scale consisted of 32 items and divided into four factors. It was translated into Turkish by Fışıloğlu and Demir (39). The Revised Dyadic Adjustment scale was developed by Busby, Crane, Larson, and Christensen (40). It consisted of 14 items and scored on a five-point scale $(1=$ never, $5=$ almost every time). It has three subscales that are consensus, satisfaction and cohesion. Turkish form that was used by Gündoğdu (41) was used in the present study. The factor analysis of the RDAS for the present study did not yield three factors. The existence of other studies (42) having used the total score from the scale, enabled the researchers to use the total score from the scale for the current study too. The internal consistency reliability of the RDAS calculated by Cronbach's alpha was 0.83 for this study.

Impact of Event Scale-Revised (IES-R): Impact of Event Scale was developed by Horowitz et al. (43) to assess the subjective distress level of a person experiences after a certain event. The scale consists of 15 items and these items made up two subscales (intrusions, and avoidance). As the scale does not consist of items related to hypervigilance, it was not able to contain all the symptoms known for the post traumatic stress disorder. Thus, Weiss and Marmar (44) added new items regarding hypervigilance dimension. After adding new items (Impact of Event Scale-R), it consisted of 22 items and these 22 items made up three subsclaes, which are, intrusions, avoidance and hypervigilance. It was translated into Turkish by Işıklı (45). Avoidance and Hypervigilance subscales were used in the current study. The internal consistency reliabilities of the avoidance and hypervigilance calculated by Cronbach's alpha were 0.70 and 0.76 respectively for this study.

\section{Procedure}

In the present study, the examined environmental factors were dyadic adjustment and perceived social support (from family, friends and significant others). Personal factors were self-efficacy, demographic variables (age, time of marriage) and prior 
trauma experiences. The impact of the event (avoidance and hypervigilance) variable was examined under the category of event related factors. The relations of cognitive processes with these factors listed before and with posttraumatic growth were examined. Furthermore, the mediating role of coping strategies on environmental factors-posttraumatic growth, individual factors-posttraumatic growth and event related factors-posttraumatic growth relation among cancer patients was also examined.

The data was collected from five different hospitals located in five different provinces of Turkey between March 2014 and April 2015. Before data collection, necessary ethical approvals were obtained from the Clinical Research Ethics Committees of Mersin University and also from Turkey Public Hospitals Institution for each of the hospitals mentioned above. After the purpose of the study was explained and confidentiality was guaranteed, informed consent was obtained from the participants. Application of each questionnaire took approximately 25 minutes.

Before statistical analysis, data were cleaned in terms of missing values and outliers. Since there were no cases with missing values, there is no need to apply any procedure for missing values. On the other hand, the 17 cases who were outliers were deleted. A total of 134 cases were examined for further analysis.

\section{Statistical analysis}

Pearson correlation coefficients were calculated to examine the relations among the variables of the study. Five separate independent sample t-tests were conducted in order to examine the group differences on study variables. Finally, in order to examine the mediating role of ways of coping on the environmental factors-posttraumatic growth, individual factors-posttraumatic growth and event related factors-posttraumatic growth relation among breast cancer patients, 24 separated mediation analyses were conducted according to the steps proposed by Baron and Kenny (46). Data was analyzed via SPSS 20.

\section{RESULTS}

Pearson correlation coefficients were calculated to examine the relations among the variables of the study (see Table 2). The correlational analysis showed that PTG is significantly and positively related to optimistic/problem focused coping $(r=$ $0.50, \mathrm{p}<0.01)$, fatalistic coping $(\mathrm{r}=0.29, \mathrm{p}<0.01)$, dyadic adjustment $(\mathrm{r}=0.19, \mathrm{p}<0.05)$, support from

Table 2. Correlation matrix for study variables

\begin{tabular}{|c|c|c|c|c|c|c|c|c|c|c|c|c|c|c|}
\hline & \multicolumn{14}{|c|}{ Correlation } \\
\hline & 1 & 2 & 3 & 4 & 5 & 6 & 7 & 8 & 9 & 10 & 11 & 12 & mean & sd \\
\hline 1. Heplessness Coping & - & & & & & & & & & & & & 12.53 & 2.88 \\
\hline 2. Fatalistic Coping & .10 & - & & & & & & & & & & & 23.67 & 3.23 \\
\hline 3. Optimistic/Problem F. Coping & $-.25 * *$ & .12 & - & & & & & & & & & & 43.36 & 4.19 \\
\hline 4. Posttraumatic Growth & -.13 & $.29 * *$ & $.50 * *$ & - & & & & & & & & & 86.58 & 14.21 \\
\hline 5. Dyadic Adjustment & $-.19 *$ & .06 & $.17^{*}$ & $.19^{*}$ & - & & & & & & & & 55.21 & 8.74 \\
\hline 6. Support From Family & -.16 & .04 & $.21 *$ & $.21^{*}$ & $.45 * *$ & - & & & & & & & 26.19 & 2.78 \\
\hline 7. Support From Friends & -.11 & .05 & .06 & .04 & .07 & .11 & - & & & & & & 23.47 & 5.71 \\
\hline 8. Support From Significant Others & .03 & .08 & -.03 & .06 & .05 & -.03 & $.42 * *$ & - & & & & & 20.70 & 7.13 \\
\hline 9. Selfefficacy & $-.36 * *$ & -.07 & $.40 * *$ & $.28^{*}$ & .15 & $.30 * *$ & .07 & .03 & - & & & & 67.00 & 12.18 \\
\hline 10. Self-blame & $.49 * *$ & -.13 & -.10 & -.13 & $-.29 * *$ & -.10 & -.06 & .10 & -.13 & - & & & 2.99 & 1.16 \\
\hline 11. Avoidance & .07 & $.27 * *$ & $.36^{* *}$ & $.39^{*}$ & .08 & .07 & -.07 & -.02 & .05 & .00 & - & & 16.88 & 6.97 \\
\hline 12. Hypervigilance & $.48 * *$ & .06 & $-.11 * *$ & -.02 & $-.20 * *$ & $-.23 * *$ & -.00 & $-.01 *$ & $.33 * *$ & $.28 * *$ & .03 & - & 8.14 & 5.79 \\
\hline
\end{tabular}

$* \mathrm{p}<.05, * * \mathrm{p}<.01, * * * \mathrm{p}<.001$ 
family $(\mathrm{r}=0.21, \mathrm{p}<0.05)$, avoidance $(\mathrm{r}=0.30, \mathrm{p}<$ $0.01)$, and self-efficacy $(\mathrm{r}=0.28, \mathrm{p}<0.01)$. As it is shown in Table 2, the correlation coefficient between dyadic adjustment and PTG $(\mathrm{r}=0.19, \mathrm{p}<$ 0.05 ) was the lowest one among these coefficients.

Five separate independent sample t-tests were conducted in order to examine the group differences on study variables. It was found that there is no significant difference between the groups regarding age (44 years and less group versus 45 years and older group), education level (high school and higher education group versus elementary education and illiterate group) and time passed since marriage (20 years and less versus 21 years and higher group). On the other hand, according to the t-test regarding time passed since the diagnosis (12 months and less, more than 12 months) there is a significant difference between the two groups only regarding the perceived social support from the family $(\mathrm{t}(132)=-2.61, \mathrm{p}<0.01)$. That is the participants in the more than 12 months group reported higher perceived social support from the family compared to the participants in the 12 months and less group. There were no significant differences between the two groups regarding time passed since the diagnosis on the remaining variables. According to the t-test analysis regarding the trauma experiences prior to $\mathrm{BC}$ diagnosis, there were significant differences between the groups. T-test analysis revealed that there was a significant difference between the two groups regarding problem focused coping style $(\mathrm{t}(132)=2.67, \mathrm{p}<0.01)$. That is the group who had no prior trauma experience had higher scores $(\mathrm{m}=44.74, \mathrm{sd}=3.76)$ on problem focused coping styles compared to the group who had prior trauma experience $(\mathrm{m}=42.71, \mathrm{sd}=4.24)$. Also, there was a significant difference between the two groups regarding post traumatic growth $(\mathrm{t}(132)=2.33, \mathrm{p}<0.05)$. That is, the group who had no prior trauma experience had higher scores $(\mathrm{m}=$ 90.69 , sd=11.55) on posttraumatic growth compared to the group who had prior trauma experience $(m=84.64, \mathrm{sd}=14.98)$. Finally, there was a significant difference between the two groups regarding helplessness coping style $(\mathrm{t}(132)=-2.49, \mathrm{p}<$ $0.05)$. That is, the group who had prior trauma experience had higher scores $(\mathrm{m}=12.95$, $\mathrm{sd}=2.81)$ on helplessness coping style compared to the group who had no prior trauma experience $(\mathrm{m}=11.65$, sd
$=2.84)$. There were no significant differences between the two groups regarding the prior trauma experiences on the remaining variables (perceived social support, dyadic adjustment, fatalistic coping, avoidance and hypervigilance).

\section{Mediation Analysis}

In the first analysis the mediation role of problem focused/optimistic coping on the dyadic adjustment and posttraumatic growth relation was examined. Results showed that the relationship between dyadic adjustment and posttraumatic growth was mediated by optimistic/problem-focused coping. Dyadic adjustment was a marginally significant predictor of posttraumatic growth $($ Beta $=0.19, \mathrm{p}=$ 0.026 ) and it was a significant predictor of optimistic/problem-focused coping (Beta $=0.17, p=$ 0.038). Optimistic/problem-focused coping was a significant predictor of posttraumatic growth $($ Beta $=0.48, \mathrm{p}<0.001)$. The final condition of mediation was also met: The standardized regression coefficient between dyadic adjustment and posttraumatic growth decreased after controlling for optimistic/problem-focused coping (from Beta $=0.19, \mathrm{p}=0.026$ to Beta $=0.10, \mathrm{p}=0.172$ ). Therefore, optimistic/problem focused coping mediated the relationship between dyadic adjustment and posttraumatic growth (see Figure 1).

The relation between perceived social support from family members and posttraumatic growth was mediated by optimistic/problem-focused coping. Perceived social support from family members was a marginally significant predictor of posttraumatic growth $($ Beta $=0.21, p=0.013)$ and it was a significant predictor of optimistic/problemfocused coping $($ Beta $=0.21, \quad \mathrm{p}=0.013)$. Optimistic/problem-focused coping was a significant predictor of posttraumatic growth $($ Beta $=0.48, \mathrm{p}<0.001)$. The final condition of mediation was also met: The standardized regression coefficient between perceived social support from family members and posttraumatic growth decreased after controlling for optimistic/problemfocused coping (from Beta $=0.21, p=0.013$ to Beta $=0.11, p=0.148)$. Therefore, optimistic/problemfocused coping mediated the relationship between perceived social support from family members and 


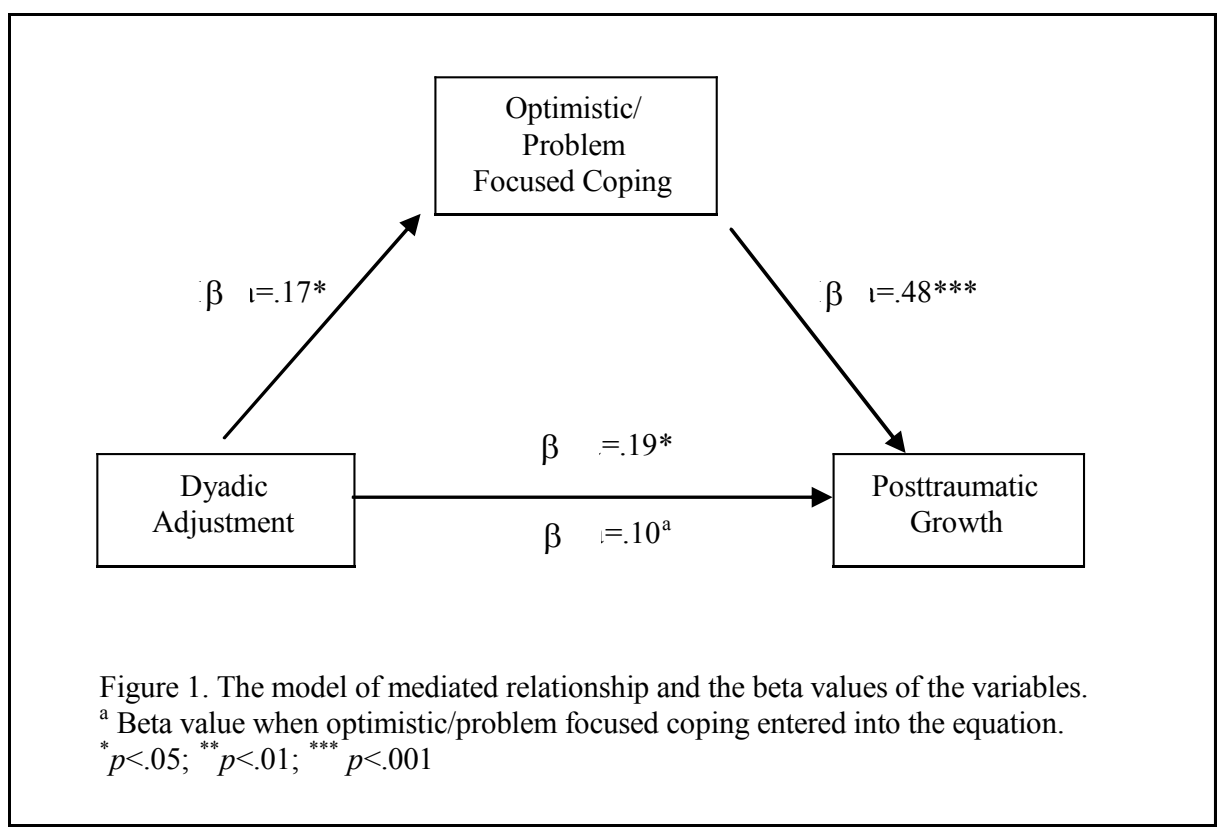

posttraumatic growth (see Figure 2).

The relationship between self-efficacy and posttraumatic growth was mediated by optimistic/problem-focused coping. Self-efficacy was a marginally significant predictor of posttraumatic growth (Beta $=0.28, \mathrm{p}<0.001)$ and it was a significant predictor of optimistic/problem-focused coping (Beta $=0.40$, $\mathrm{p}<0.001)$. Optimistic/problem-focused coping was a significant predictor of posttraumatic growth (Beta $=0.48, \mathrm{p}<0.001)$. The final condition of mediation was also met: The standardized regression coefficient between self-efficacy and posttraumatic growth decreased after controlling for optimistic/problem-focused coping (from Beta $=0.28, \mathrm{p}$ $=0.001$ to Beta $=0.09, \mathrm{p}=0.261)$. Therefore, problem-focused coping mediated the relation between self-efficacy and posttraumatic growth (see Figure 3).

The relation between avoidance and posttraumatic growth was partially mediated by optimistic/problem-focused coping. Avoidance was a significant predictor of posttraumatic growth $($ Beta $=0.39, p$ $<0.001)$ and it was a significant predictor of optimistic/problem-focused coping (Beta $=0.36, p<$ 0.001). Optimistic/problem-focused coping was a significant predictor of posttraumatic growth $($ Beta $=0.48, p<0.001)$. The final condition of mediation was also met: The standardized regres- sion coefficient between avoidance and posttraumatic growth decreased after controlling for optimistic/problem-focused coping (from Beta $=0.39, \mathrm{p}$ $<0.001$ to $B e t a=0.24, p=0.002)$. The mediator role of optimistic/problem-focused coping was confirmed by Sobel test (Sobelz $=3.41, \mathrm{p}<0.01$ ). Therefore, optimistic/problem-focused coping partially mediated the relationship between avoidance and posttraumatic growth.

The relation between avoidance and posttraumatic growth was partially mediated by fatalistic coping. Avoidance was a significant predictor of posttraumatic growth $($ Beta $=0.39, \mathrm{p}<0.001)$ and it was a significant predictor of fatalistic coping (Beta= $0.27, \mathrm{p}<0.001)$ Fatalistic coping was a significant predictor of posttraumatic growth $($ Beta $=0.20, p$ $=0.016)$. The final condition of mediation was also met: The standardized regression coefficient between avoidance and posttraumatic growth decreased after controlling for fatalistic coping (from Beta $=0.39, \mathrm{p}<0.001$ to Beta $=0.34, \mathrm{p}<$ 0.001) (see Figure 4). The mediator role of fatalistic coping was confirmed by Sobel test (Sobelz = $1.97, \mathrm{p}<0.05)$. Therefore, fatalistic coping partially mediated the relation between avoidance and posttraumatic growth.

In terms of other variables used in this study, the conditions of mediation were not fulfilled. 


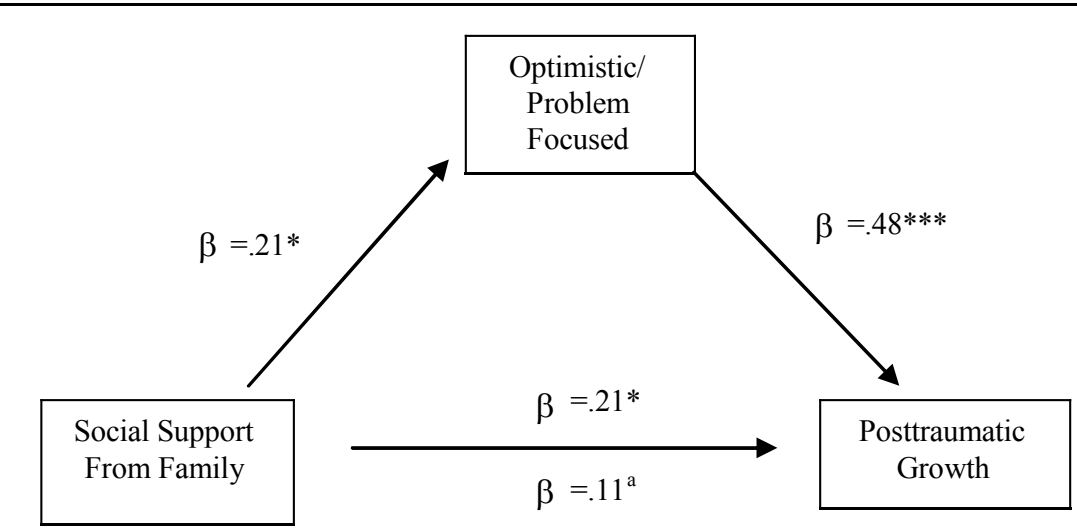

Figure 2. The model of mediated relationship and the beta values of the variables.

${ }^{a}$ Beta value when optimistic/problem focused coping entered into the equation.

${ }^{*} p<.05 ;{ }^{* *} p<.01 ;{ }^{* * *} p<.001$

Therefore, the relation between the remaining variables and posttraumatic growth was not mediated by coping.

\section{DISCUSSION}

The current study was conducted to examine the relation of environmental, event related, personal and cognitive factors with posttraumatic growth (PTG). For this reason, perceived social support and dyadic adjustment were examined as the environmental factors; demographic variables, prior trauma experience and self-efficacy were examined as the personal factors; avoidance, hypervigilance and ways of coping were examined as the event related and the cognitive factors. The relation of these variables with PTG and also the mediator role of ways of coping in environmental factorsPTG, event related factors-PTG and personal factors-PTG relations were examined.

First of all, the effects of demographic variables (e.g., age, education, time passed since the diagnosis, prior trauma experience and time passed since the marriage) on the variables of the study were

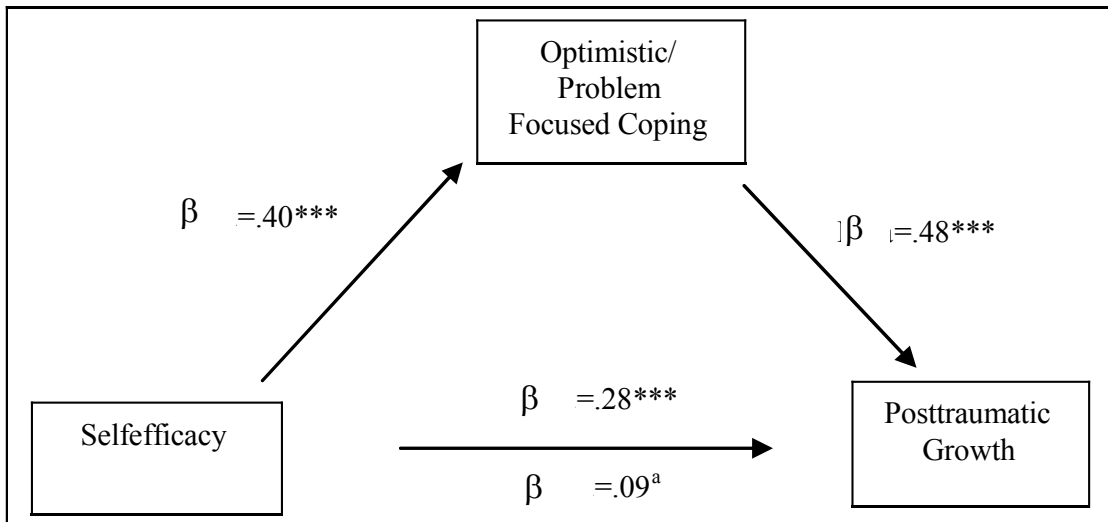

Figure 3. The model of mediated relationship and the beta values of the variables. ${ }^{a}$ Beta value when optimistic/problem focused coping entered into the equation. ${ }^{*} p<.05 ;{ }^{* *} p<.01 ;{ }^{* * *} p<.001$ 


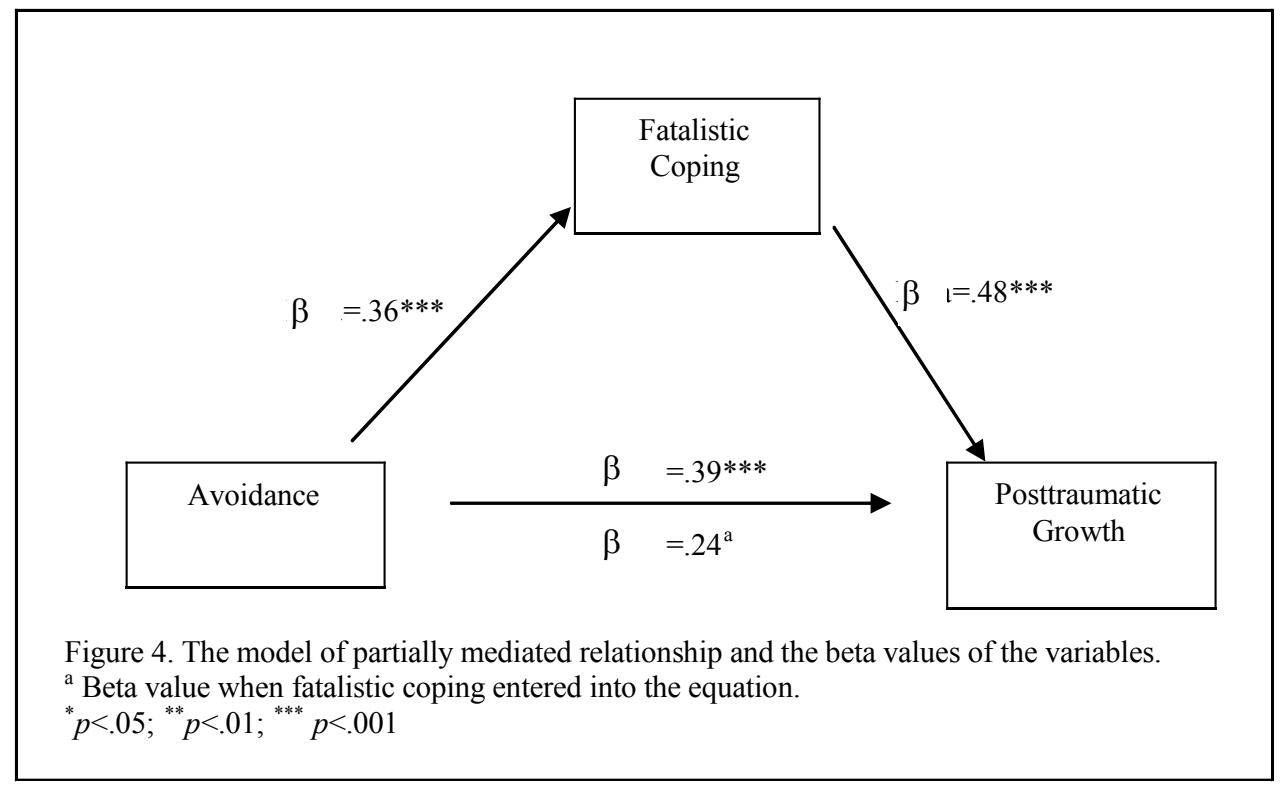

investigated. The findings of the current study supported previous findings only partially regarding demographics predicting PTG. To begin with, age was not found to be related to PTG in the current study. Similar with this finding, Svetina and Nastran (47) found that age did not account for the differences in breast cancer patients. On the other hand, Bellizi (48) found that, age was related to PTG that is, the younger subjects experience more PTG when compared to older cancer patients. Similar to this finding Pinquart et al. (49) stated that the younger the age of patients, the higher the level of PTG. Education is another variable, which was found to be related to PTG. Some studies stated that there is a negative relation between education and PTG (50); on the other hand, some other researchers reported that there is a positive relation between education and PTG (51). Moreover other studies reported that education does not account for the differences in BC patients (49). Similarly with Svetina and Nastran's (47) findings, the results of the current study suggested that there is a non-significant relation between education and PTG.

In terms of other variables regarding the demographics information, prior trauma experience was significantly related to PTG. When two groups were compared, there was a significant difference in PTG that is, having no prior trauma experience predicted PTG while having prior trauma experi- ence did not. However, these results are questionable. According to Güneş (52), it was thought that the group who has prior trauma experience would be more likely to show PTG compared to the group who has no prior trauma experience due to their experiences about coping with the prior traumatic events. However, according to the findings of Güneş's study (52), this hypothesis was not proven. Contrary to this finding, the current study revealed that having prior trauma experience did not predict PTG while having no prior trauma experience predicted PTG. According to Janoff- Bulman (53), to be able to experience PTG, one has to manage the traumatic event successfully at least to an extend. This may be related with the resolution of the prior trauma experience. In other words, if the person could not cope successfully with the prior trauma experience, this person may not show PTG after being diagnosed $\mathrm{BC}$ due to the unsuccessful coping schemas about traumatic events and the perception of the traumatic experience. However, in the current study, the data about how the person dealt with the prior trauma experience was not collected. Therefore, this might be the reason of the current findings. On the other hand on of the result of the current study revealed that; the group who had prior trauma experience uses more helplessness coping and less optimistic/problem focused coping when compared to the group who had no prior trauma experience. This information could be an explanation for the finding regarding PTG and 
prior trauma experiences.

Perceived social support (from family, friends and significant others) and dyadic adjustment were examined as the environmental factors. The current study showed that only social support from the family predicted PTG. However, there is an inconsistency regarding PTG and social support relation in the literature. Although there are studies showing that social support predicted PTG $(17,49,54$, $55,56)$; there are also other studies that illustrating that social support did not predict PTG $(57,58,59)$. Findings of the current study showed that perceived social support from the family changes over time elapsed since diagnosis. According to the results of the current study the participants in the more than 12 months group reported higher perceived social support from the family compared to the participants in the 12 months and less from the diagnosis group.

Another environmental factor was the dyadic adjustment. According to the findings of the current study, as the dyadic adjustment score increased the PTG level also increased. Similar with the findings of the current study, O'Leary and colleagues (60) stated that dyadic adjustment influences the PTG responses of the participants. Moreover, it was stated that the perceived support from the marital relationship was positively related with PTG (50). From this point of view, it can be said that, findings regarding the dyadic adjustment are consistent with the related literature.

When it comes to personal factors, self-efficacy, consistent with the literature, was found to be positively related to PTG. According to Lotfi-Kashani et al. (61) self-efficacy was significantly related with PTG. In addition, Benight and Bandura (62) stated that self-efficacy moderates psychosocial functioning.

Event related factors dimension consisted of avoidance and hypervigilange variables. Şenol-Durak (63) found that avoidance-active coping style and hypervigilance-active coping style relations were significantly positive. Furthermore, it was stated that the relations between PTG-avoidance and PTG-hypervigilance were also significantly positive
(63). Similarly, in the current study, it was found that, avoidance-PTG relation was significantly positive. However there was no significant relation between PTG- hypervigilance variables in the current study.

Many studies examine the concept of PTG and its relation to ways of coping. According to Bellizzi and Blank (64), the best predictor of PTG is active coping. Schmidt et al. (50) stated that active coping was significantly associated with PTG. Furthermore, it was stated that problem focused coping was a good predictor of PTG in many other studies $(10,14,16,65)$. Fatalistic coping was also a predictor of PTG (16). Consistent with these findings, in the current study the PTG- problem focused/optimistic coping and PTG-fatalistic coping relations were found to be significant.

According to the results of the mediation analyses, problem focused coping/optimistic coping, fully mediated the relation between PTG and one of personal factors: PTG-self-efficacy relation. Similar with this finding, there are studies showing that the mediation role of problem focused coping in the relation between PTG and personal factors like: dispositional optimism-PTG relation (14); extroversion-PTG, responsibility-PTG relations (65).

Post-traumatic growth, as the definition implies, is a process in which one develops more positive and new perspectives about the person himself/herself, his/her relationships and his/her life.However, someone with a negative coping style, such as helplessnes coping style, does not have the courage and energy to develop such new perspectives. Helplessness as a coping style means that one can not actively strive to get rid of the negative effects of trauma. Therefore, a person with a negative coping style can not be expected to develop PTG. Findings of the current study supported these interpretation. It was found that optimistic/problem focused coping fully mediated the relationships between perceived social support-PTG, dyadic adjustment-PTG and self efficacy-PTG. It seems that the optimistic/positive coping style contributed to the enhancement of the relationships between the sources that the person has, such as dyadic 
adjustment, social support and self-efficacy, and the PTG. Besides having these resources, having a positive coping style seems to lead to an increase in the contribution of these resources. According to the findings of the current study there are two coping styles, optimistic/problem focused coping and fatalistic coping, that partially mediated the relationship between PTG and avoidance. Avoidance reactions are cognitive and behavioral reactions by which the person tries to consciously suppress the feelings, memories, and situations evoked by the traumatic experience. In this respect, avoidance reactions are thought to increase the likelihood of a person being less exposed to the adverse effects of traumatic events and developing PTG. This assumption was supported by the findings of the current study. It was found that optimistic/problem focused coping and fatalistic coping styles partially mediated the relationship between PTG and avoidance. Both of these coping styles mean that one has a more accepting and positive perspective regarding the traumatic event. Therefore, these two coping styles seem to contribute to the relationship between avoidance and PTG.

In the present study, there is no information about how the person dealt with the prior trauma experience. Thus, direct conclusions regarding why there was not a significant relation between PTG and prior trauma experiences could not be inferred. This is one of the limitations of this study. Another limitation is the lack of data regarding the stage of the illness. Also, time passed since the diagnosis was very different among subjects (differs from 2 months to 180 months) and this difference could affect coping strategies. Not controlling for this difference is another limitation of the current study. Finally, the cross-sectional nature of the study, the lack of control group, lack of measurements regarding post traumatic stress disorder sypmtoms and lack of assessment regarding psychiatric illness can be counted as the other limitations of the current study.

To sum up, taking into account other predictive variables of PTG in different cancer types and other chronic disorders for both sexes would be important in planning interventions which aimed to promote psychosocial resources. This study is also important because the effect of marital adjustment and marital satisfaction on posttraumatic growth in breast cancer patients is an issue which is not well studied with Turkish sample. Besides these strengths, this study is also important in terms of having a great number of participants (134) that would not be underestimated for a specific clinical sample, such as breast cancer.

Correspondence address: Research Assistant Zumrut Bellur, Mersin University, Faculty of Arts and Sciences, Department of Psychology, Mersin, Turkey zumrut_bellur@hotmail.com 


\section{REFERENCES}

1. Affleck G, Tennen H. Construing benefits from adversity: Adaptational significance and dispositional underpinnings. J Pers, 1996; 64, 900-922.

2. Tedeschi RG, Calhoun LG. Trauma and transformation: Growing in the aftermath of suffering. Thousand Oaks, CA: Sage Press, 1995.

3. Tedeschi RG, Park CL, and Calhoun LG. Posttraumatic growth: Conceptual issues. In R. G. Tedeschi, C. L. Park and L. G. Calhoun (Eds.), Posttraumatic growth: Positive changes in the aftermath of crisis. NJ, Erlbaum Press, pp. 1-22

4. Tedeschi RG, Calhoun LG. The posttraumatic growth inventory: Measuring the positive legacy of trauma. J Trauma Stress 1996; 9: 455-471.

5. Nolen-Hoeksema S, Davis C. Positive response to loss. New York, Oxford University Press, 2004.

6- Davis CG, Nolen-Hoeksema S, Larson J. Making sense of loss and benefiting from the experience: two construals of meaning. J Pers Soc Psychol, 1998; 75(2): 561-574.

7. Park CL, Folkman S. Meaning in the context of stress and coping. Rev Gen Psychol, 1997; 1(2): 115-144.

8. Filipp SH. A three-stage model of coping with stress and trauma,"in Posttraumatic Stress Disorder: A Lifespan Developmental Perspective. Edited by Maercker A, Schu?tzwohl M, Solomon Z. Seattle, Hogrefe and Huber Press, 1999, pp. 43-78.

9. Taylor SE. Adjustment to threatening events: A theory of cognitive adaptation. Am Psychol, 1983; 38: 1161-1173.

10. Schaefer JA, Moos RH. Life crises and personal growth. In B. N. Carpenter (Ed.), Personal coping. Theory, research, and application. Westport, CT: Praeger Press, 1992, pp. 149-170.

11. Schaefer JA, Moos RH. The context for posttraumatic growth: Life crises, individual and social resoruces, and coping. Edited by Tedeschi RG, Park CL and Calhoun LG, Posttraumatic growth: Positive changes in the aftermath of crisis Mahwah. NJ, Erlbaum Press, 1998, pp. 99-125.

12. Zemore R, Shepel LF. Effects of breast cancer and mastectomy on emotional support and adjustment. Soc Sci Med, 1989; 28 (1): 19-27.

13. Moos RH, Schaefer JA. Coping resources and processes: Current concepts and measures. Edited by Goldberger L, Breznitz S, Handbook of stress: Theoretical and clinical aspects. New York: Free Press, 1993, pp. 234-257.

14. Büyükaşık-Çolak C, Gündoğdu-Aktürk E, Bozo Ö. Mediating role of coping in the dispositional optimism-posttraumatic growth relation in breast cancer patients. J Psychol, 2012; 146(5): 471-483.

15. Schwartzberg SS. Vitality and growth in HIV-infected gay men. Soc Sci Med, 1994; 38: 593-602.

16. Dirik G. Posttraumatic growth and psychological distressamong rheumatoid arthritis patients: An evaluation within the conservation of resources theory. Middle East Technical University, Unpublished doctorate thesis, 2006.

17. Elçi Ö. Predictive values of social support, coping styles and stress level in posttraumatic growth and burnout levels among the parents of children with autism. Middle East Technical University, Unpublished doctorate thesis, 2004.

18. Joseph S, Linley PA. Trauma recovery and growth. New Jersey: John Wiley and Sons, 2008

19. Karancı AN, Erkam A. Variables related to stress?related growth among Turkish breast cancer patients. Stress Health, 2007; 23(5): 315-322.

20. Bozo Ö, Gündoğdu E, Büyükaşik-Çolak C. The moderating role of different sources of perceived social support on the dispositional optimism-posttraumatic growth relationship in postoperative breast cancer patients. J Health Psychol, 2009; 14(7): 1009-1020.

21. Bruce M. A systematic and conceptual review of posttraumatic stress in childhood cancer survivors and their parents. Clin Psychol Rev, 2006; 26: 233-256.

22. Kangas M, Henry JL, Bryant RA. Posttraumatic stress disorder following cancer: A conceptual and empirical review. Clin Psychol Rev, 2002; 22(4): 499-524.

23. Turkish Health Ministry. http://kanser.gov.tr/Dosya/ca_istatistik/2014-RAPOR._uzun.pdf. Date: 2 November 2016

24. Zimet GD, Dahlem NW, Zimet SG, Farley GK. The multidimensional scale of perceived social support. J Per Assess, 1988; 52(1): 30-41.

25. Eker D, Arkar H. Perceived social support: psychometric properties of the MSPSS in normal and pathological groups in a developing country. Soc Psychiatry Psychiatr Epidemiol, 1995; 30(3): 121-126.

26. Eker D, Arkar H, Yaldız H. Factorial structure, validity, and reliability of revised form of the multidimensional scale of perceived social support. Turk Psikiyatri Derg, 2001; 12(1): 17-25.

27. Kılıç C. Posttraumatic growth and its predictors. Paper presented at the IV. International Psychological Trauma Meeting, 2005

28. Dirik G, Karanci AN. Variables related to posttraumatic growth in Turkish rheumatoid arthritis patients. J Clin Psychol Med Settings, 2008; 15(3): 193-203.

29. Bellizzi KM, Smith AW, Reeve BB, Alfano CM, Bernstein L, Meeske K, Baumgartner KB, Ballard-Barbash RR. Posttraumatic growth and health-related quality of life in a racially diverse cohort of breast cancer survivors. J Health Psychol, 2010; 15(4): 615-626.

30. Park CL, Lechner SC. Measurement issues in assessing growth following stressful life experiences. Edited by Calhoun LG, Tedeschi RG. Handbook of posttraumatic growth: Research and practice, NJ, Mahwah Press, 2006, 47-67.

31. Folkman S, Lazarus RS. An analysis of coping in a middleaged community sample. J Health Soc Behav, 1980; 21: 219-239.

32. Folkman S, Lazarus RS. If it changes it must be a process: Study of emotion and coping during three stages of a college examination. J Pers Soc Psychol, 1985; 48: 150-170.

33. Ucman P. Ulkemizde calisan kadinlarda stresle basa cikma ve psikolojik rahatsizliklar [Coping with stress and psychological problems of working women in our country]. Tu?rk Psikoloji Dergisi, 1990; 7(24): 58-75. 
34. Karancı NA, Alkan N, Aksit B, Sucuoglu H, Balta E. Gender differences in psychological distress, coping, social support, and related variables following the 1995 Dinar (Turkey) earthquake. N Am J Psychol, 1999; 1(2): 189-204.

35. Bell AC, D'Zurilla TJ. Problem-solving therapy for depression: a meta-analysis. Clin Psychol Rev, 2009; 29(4): 348-353.

36. Sherer M, Maddux JE, Mercandante B, Prentice-Dunn S, Jacobs B, Rogers RW. The self-efficacy scale: Construction and validation. Psychol Rep, 1982; 51(2): 663-671.

37. Yıldırım F, İlhan İÖ. Genel Özyeterlilik Ölçeği Türkçe Formunun Geçerlilik ve Güvenilirlik Çalışması. Türk Psikiyatri Derg, 2010; 21(4): 301-308.

38. Spanier GB. Measuring dyadic adjustment: Newscales for assesing the quality of marriage and similar dyads. J Marriage Fam, 1976; 38: 15-27.

39. Fışıloğlu H, Demir A. Applicability of the Dyadic Adjustment Scale for measurement of marital quality with Turkish couples. Eur J Psychol Assess, 2000; 16(3): 214-218.

40. Busby DM, Crane DR, Larson JH, Christensen C. A revision of the DAS for use with distressed and nondistressed couples: Construct hierarchy and multidimensional scales. J Marital Fam Ther, 1995; 21(3): 289-308.

41. Gündoğdu A. Relationship between self-construals and marital quality. Middle East Technical University, unpublished master thesis, 2007

42. Civan A. Eşlerin duygu dışavurum tarzları ile algılanan evlilik kalitesinin ilişkisi ve duygusal farkındalığın rolü. Mersin University, unpublished master thesis, 2011.

43. Horowitz M, Wilner M, Alvarez W. Impact of event scale: A measure of subjective stress. Psychosom Med, 1979; 41: 209-218.

44. Weiss DS, Marmar CR. The impact of event scale revised. Edited by Wilson JP, Keane TM. Assessing Psychological Trauma and PTSD London: The Guilford Press, 1997, pp. 399411.

45. Işıkı S. Travma sonrası stres belirtileri olan bireylerde olaya ilişkin dikkat yanlılı̆̆ı, ayrışma du?zeyi ve çalışma belleği uzamı arasındaki iliskiler. Hacettepe University, unpublished doctorate thesis 2006 .

46. Baron RM, Kenny DA. The moderator-mediator variable distinction in social psychological research: Conceptual, strategic, and statistical considerations. J Pers Soc Psychol, 1986; 51(6): 1173-1182

47. Svetina M, Nastran K. Family relationships and post-traumatic growth in breast cancer patients. Psychiatr Danub, 2012; 24(3): 298-306.

48. Bellizzi KM. Expressions of generativity and posttraumatic growth in adult cancer survivors. Int J Aging Hum Dev, 2004; 58(4): 267-287.

49. Pinquart M, Fröhlich C, Silbereisen RK. Cancer patients' perceptions of positive and negative illness-related changes. J Health Psychol, 2007; 12(6): 907-921.

50. Weiss T. Correlates of posttraumatic growth in married breast cancer survivors. J Soc Clin Psychol, 2004; 23(5): 733-746.

51. Updegraff JA, Taylor SE, Kemeny ME, Wyatt GE. Positive and negative effects of HIV infection in women with low socioeconomic resources. Pers Soc Psychol Bull, 2002; 28(3): 382-394.

52. Güneş $H$. Travma sonrası gelişim olgusunun niceliksel ve niteliksel yöntemlerle açık kalp ameliyatı geçiren coroner kalp hastalarında incelenmesi. Ankara University, unpublished doctorate thesis, 2009

53. Janoff-Bulman R. Posttraumatic growth: Three explanatory models. Psychol Inq, 2004; 15(1): 30-34.

54. Dirik G. Posttraumatic growth and psychological distressamong rheumatoid arthritis patients: An evaluation within the conservation of resources theory. Middle East Technical University, unpublished doctorate thesis, 2006.

55. Park CL, Fenster JR. Stress-related growth: Predictors of occurrence and correlates with psychological adjustment. J Soc Clin Psychol, 2004; 23(2): 195-215.

56. Dunn J, Occhipinti S, Campbell A, Ferguson M, Chambers SK. Benefit finding after cancer: The role of optimism, intrusive thinking and social environment. J Health Psychol, 2011; 16 (1): 169-177.

57. Cordova MJ, Cunningham LL, Carlson CR, Andrykowski MA. Posttraumatic growth following breast cancer: a controlled comparison study. Health Psychol, 2001; 20(3): 176.

58. Widows MR, Jacobsen PB, Booth-Jones M, Fields KK. (2005). Predictors of posttraumatic growth following bone marrow transplantation for cancer. Health Psychol, 2005; 24(3): 266-273

59. Schmidt SD, Blank TO, Bellizzi KM, Park CL. The relationship of coping strategies, social support, and attachment style with posttraumatic growth in cancer survivors. J Health Psychol, 2012; 17(7): 1033-1040.

60. O'Leary VE, Alday CS, Ickovics JR. Models of life change and posttraumatic growth. Edited by Tedeschi RG, Park CL, Calhoun LG. Posttraumatic growth: Positive changes in the aftermath of crisis. New Jersey: Lawrence Erlbaum Associates, Publishers, 1998, pp. 127-152

61. Lotfi-Kashani F, Vaziri S, Akbari ME, Kazemi-Zanjani N, Shamkoeyan L. Predicting post traumatic growth based upon self-efficacy and perceived social support in cancer patients. Iran J Cancer Prev, 2014; 7(3): 115-123.

62. Benight CC, Bandura A. Social cognitive theory of posttraumatic recovery: The role of perceived self-efficacy. Behav Res Ther, 2004; 42(10): 1129-1148.

63. Şenol-Durak E. Environmental and individual resources, perception of the event, cognitive processing and coping as factors leading to posttraumatic growth among the survivor of myocardial infarction patients and their spouses. Middle East Technical University, unpublished doctorate thesis, 2007.

64. Bellizzi KM, Blank TO. Predicting posttraumatic growth in breast cancer survivors. Health Psychol, 2006; 25(1): 47-56.

65. Önder N. The mediating role of coping strategies in the basic personality traits-ptg and locus of control-ptg relationships in breast cancer patients. Middle East Technical University, unpublished master thesis, 2012. 